\title{
LIMONENE QUANTIFICATION BY GAS CHROMATOGRAPHY WITH MASS SPECTROMETRY (GC-MS) AND ITS EFFECTS ON HYDROGEN AND VOLATILE FATTY ACIDS PRODUCTION IN ANAEROBIC REACTORS
}

\author{
Franciele Pereira Camargo ${ }^{\mathrm{a},(0)}$, Arnaldo Sarti ${ }^{\mathrm{b}, \mathrm{c}}$, Alberto Camilo Alécio ${ }^{\mathrm{b}}$, Carolina Aparecida Sabatini ${ }^{\mathrm{a}}$, Maria Angela \\ Tallarico Adorno ${ }^{\mathrm{a}}$, Iolanda Cristina Silveira Duarte ${ }^{\mathrm{d}}$ and Maria Bernadete Amâncio Varesche ${ }^{\mathrm{a}, *}$ \\ aDepartamento de Hidráulica e Saneamento, Escola de Engenharia de São Carlos, Universidade de São Paulo, 13566-590 São \\ Carlos - SP, Brasil

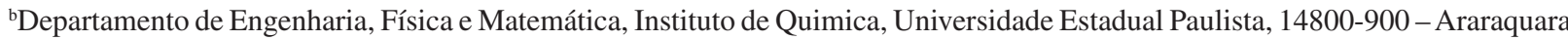 \\ - SP, Brasil \\ 'Instituto de Pesquisa em Bioenergia, Universidade Estadual Paulista, 13500-230 Araraquara - SP, Brasil \\ ${ }^{d}$ Departamento de Biologia, Universidade Federal de São Carlos, 18052-780, Sorocaba - SP, Brasil
}

Recebido em 06/01/2020; aceito em 13/04/2020; publicado na web em 29/05/2020

\begin{abstract}
The inhibition effect of limonene on the organisms involved in anaerobic reactors may affect obtaining $\mathrm{H}_{2}$ in this process. Rapid and precise limonene quantification is desirable to characterize wastewaters. The objective of this research was to develop a Gas Chromatography Coupled to Mass Spectrometry (GC-MS) method to determine limonene concentration in liquid samples from batch reactors applied to $\mathrm{H}_{2}$ production at $30{ }^{\circ} \mathrm{C}$. Method validation was carried out through calibration curves ( 3 to $20 \mathrm{mg} \mathrm{L}^{-1} \mathrm{of}$ limonene), in addition to evaluating its precision $(\mathrm{CV}=0.1 \%)$, linearity $\left(\mathrm{R}^{2}=0.979\right)$, limits of detection $\left(1.7 \mathrm{mg} \mathrm{L}^{-1}\right)$ and quantification (4.2 $\left.\mathrm{mg} \mathrm{L}^{-1}\right)$. Its inhibitory effect was evaluated with increasing concentrations of limonene (without addition to $2000 \mathrm{mg} \mathrm{L}^{-1}$ ). Limonene affected the starting time of $\mathrm{H}_{2}$ production $(\lambda)$, since $\lambda$ was $8.7 \mathrm{~h}$ in control assays and $15 \mathrm{~h}$ with $2000 \mathrm{mg} \mathrm{L}^{-1}$ of limonene. The same was observed for obtaining $\mathrm{H}_{2}$, since $19.5 \mathrm{mmol} \mathrm{H}_{2} \mathrm{~L}^{-1}$ was obtained in control assays and $8.7 \mathrm{mmol} \mathrm{H}_{2} \mathrm{~L}^{-1}$ was obtained in assays with $2000 \mathrm{mg} \mathrm{L}^{-1}$ of limonene. This method was effective for limonene determination in liquid samples from batch reactors and could be used for characterization and control of anaerobic reactors.
\end{abstract}

Keywords: wastewater; sewage sludge; anaerobic digestion; hydrogen; volatile fatty acids; limonene.

\section{INTRODUCTION}

Essential oils (EOs) are natural and volatile aromatic compounds, formed as secondary metabolite by some plant species, which account for $0.3-0.5 \%$ in in natura citrus peel waste $(\mathrm{CPW}) .{ }^{1}$ Its synthesis occurs in all plant organs (stem, flowers, leaves, seeds, fruits, roots, wood), and it is stored in specialized secretory cells or trichomes. Because of its medicinal, antiseptic and microbicidal properties, in addition to its fragrance, essential oils are used as additives in pharmaceutical and food industry products, such as anesthetics, analgesics, sedatives, anti-inflammatories, among others..$^{2,3}$

Since essential oils are metabolized mainly as plant defense mechanism, these compounds may present toxicity to other organisms because of their lipophilic affinity. ${ }^{4}$ The lipophilic nature causes their passage through both the cell wall and the cytoplasmic membrane, destabilizing polysaccharides and fatty acids, in addition to the loss of ions in bacterial cells, leading them to lysis. ${ }^{5}$ Limonene, a monocyclic monoterpene known as D-limonene or (R)-(+)-4-isoproprenyl-1methylcyclohexane (Figure 1), is the main constituent of essential oils in most citrus species, such as lemon, orange, mandarin, lime and grapefruit. ${ }^{6,7}$

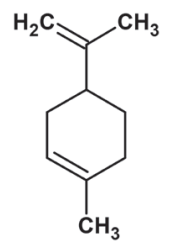

Figure 1. Chemical structure of limonene. Drawn in ChemSketch (ACD, 2019)

*e-mail: varesche@sc.usp.br
The limonene content in citrus processing waste is considered as one of the major obstacles to its reuse for biogas production. Its minimum concentration for inhibition is estimated to be approximately $200 \mathrm{mg} \mathrm{kg}^{-11,7,8}$ and since the concentrations in CPW generally exceed this limit, the inhibitory effect of this substance is always expected. ${ }^{9}$

Under aerobic conditions, limonene degradation occurs in approximately 14 days, however there is still insufficient data regarding this process under anaerobic conditions. In anaerobic environment, limonene has greater toxicity; however, the mechanisms are still unclear. Limonene toxicity can be attributed both to the greater sensitivity of anaerobic organisms and to low partial pressure of oxygen in the system, resulting in less oxidation. ${ }^{9}$

Calabrò et al. ${ }^{1}$ described the formation of p-cymene after limonene biodegradation in anaerobic environments, in which limonene is more toxic than p-cymene, ${ }^{10}$ justifying the longer biomass adaptation time, proportional to higher limonene concentrations and to microbial adaptation after this period. The authors observed longer $\lambda$ in assays with higher limonene concentration; however, methane production reached final production values $\left(370 \mathrm{CH}_{4} \mathrm{~g}^{-1} \mathrm{TVS}\right)$ similar to control assays.

There are few studies regarding limonene content in anaerobic reactors for the inhibition of microbial activity. However, Bakkali et $a l .{ }^{5}$ described the effect of several essential oils and their cytotoxicity on model microorganisms, concluding that citrus essential oils are toxic in concentrations between $0.2-25.6 \mathrm{mg} \mathrm{L}^{-1}$ for Escherichia coli, Klebsiella pneumoniae, Pseudomonas aeruginosa and Bacillus subtilis. Lotito et al. ${ }^{2}$ observed methanogenic inhibitory effect at initial concentrations above $150 \mathrm{mg} \mathrm{L}^{-1}$ of limonene. Thus, the quantification of wastes or wastewater limonene content is essential for process control. 
Several methods could be used to determine limonene content, such as Molecular Absorption Spectroscopy (UV-Vis), ${ }^{11}$ Gas Chromatography with Flame Ionization Detection (GC-FID), Selected Ion Monitoring Mass Spectrometry (SIM), ${ }^{12}$ Gas Chromatography with glass capillary Columns, ${ }^{13}$ Ultraviolet Ion Mobility Spectrometry (IMS),${ }^{14}$ High Performance Liquid Chromatography (RP-HPLC) ${ }^{15}$ and different Gas Chromatography conditions Coupled to Mass Spectrometry (GC-MS). ${ }^{13,16,17}$ According to Adorno et al. ${ }^{18}$ methods that involve direct headspace analysis are more advantageous when compared to those with direct injection of liquid sample into the chromatographic column, preserving its life time.

GC-MS was used for limonene determination in citrus samples, ${ }^{19}$ however, data regarding the application of this method in samples from anaerobic reactors, which are commonly fed with wastewater, are still scarce. The objective of this study was to develop and validate a new GC-MS method for limonene quantification, as well as to apply it in samples from anaerobic reactors. Therefore, batch assays were carried out to verify the possible inhibition of hydrogen production in reactors without limonene addition to $1500 \mathrm{mg} \mathrm{L}^{-1}$ of limonene.

\section{EXPERIMENTAL}

\section{Reagents}

Limonene standard solution was made with (R)-(+)-limonene $\left(\mathrm{C}_{10} \mathrm{H}_{16}\right)$ with $90 \%$ purity (Sigma Aldrich-62122). All other reagents (ethanol and n-hexane) were of analytical purity (>98\%).

\section{Equipment and conditions}

Limonene content was determined by Gas Chromatography, MassHunter software, coupled to Mass Spectrometer (GC-MS Agilent), model 7890B (gas chromatograph) and MS 5977A (mass spectrometer), injecting $250 \mu \mathrm{L}$ of headspace samples, and using the parameters shown in Table 1 . The chromatographic condition was defined by peak resolution analysis.

\section{Sample preparation}

Liquid anaerobic reactor samples were collected at the end of the operating cycle and centrifuged at $9000 \mathrm{rpm}$ for 5 minutes, and preserved at $-20{ }^{\circ} \mathrm{C}$, without adding any substance. Biogas samples from the headspace were collected periodically (every 2 hours) with a butyl cap using a manual gas-tight syringe (Figure 2).The samples were diluted in MilliQ ${ }^{\circledR}$ water as needed, for later analysis in the calibration curve developed and described in the subsequent items.

\section{Calibration curve}

Calibration curve of standard limonene solutions were performed in triplicate. Dilutions were performed in ultra-purified water and ethanol p.a. was used as solvent to obtain concentrations of 3.0; 6.0; 9.0; $12.0 ; 15.0 ; 18.0$ and $20.0 \mathrm{mg} \mathrm{L}^{-1}$.

\section{Method validation}

Linearity, instrumental precision, detection and quantification limits were established and conducted according to recommendations in Ribani et al. ${ }^{20}$ Duarte et al. ${ }^{21}$ and Adorno et al. ${ }^{18}$ following ANVISA (Agência Nacional de Vigilância Sanitária) specifications. ${ }^{22}$

\section{Linearity}

Detector response linearity for calibration curve was evaluated by
Table 1. Operation specifications for GC/MS

\begin{tabular}{|c|c|}
\hline \multicolumn{2}{|c|}{ Gas Chromatograph } \\
\hline Analytical Column & $\begin{array}{c}\text { Agilent HP 5 MS } \\
(30 \mathrm{~m} \times 0.25 \mathrm{~mm} \times 0.25 \mu \mathrm{m})\end{array}$ \\
\hline Injector-Port & Split: 10:1 \\
\hline GC Inlet Temp & $230^{\circ} \mathrm{C}$ \\
\hline Carrier-Gas & $\mathrm{He}$ \\
\hline Injection Volume & $250 \mu \mathrm{L}$ \\
\hline \multicolumn{2}{|c|}{ Automatic injector } \\
\hline Model & PAL RSI 85 \\
\hline Incubation Temperature & $100^{\circ} \mathrm{C}$ \\
\hline Time of incubation & $10 \mathrm{~min}$ \\
\hline \multicolumn{2}{|c|}{ Oven Program } \\
\hline Temperature & $40^{\circ} \mathrm{C}$ \\
\hline Hold Time & $3 \mathrm{~min}$ \\
\hline Rate & $10{ }^{\circ} \mathrm{C}$ \\
\hline Temperature & $100^{\circ} \mathrm{C}$ \\
\hline Rate & $60^{\circ} \mathrm{C}$ \\
\hline Temperature & $220^{\circ} \mathrm{C}$ \\
\hline \multicolumn{2}{|c|}{ Mass Spectrometer } \\
\hline Auxiliary heat & $240^{\circ} \mathrm{C}$ \\
\hline Full scan Method Mass range & $\mathrm{m} / \mathrm{z} 50$ to 550 \\
\hline
\end{tabular}

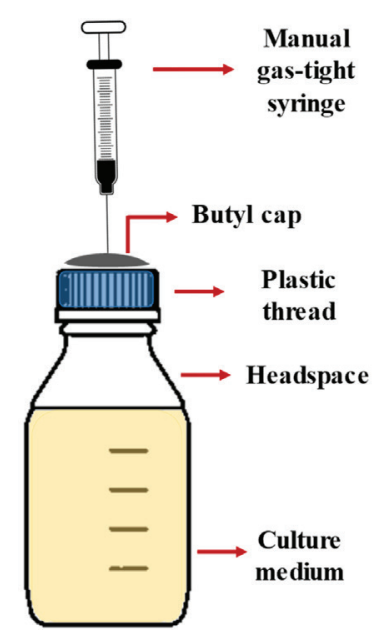

Figure 2. Static headspace sampling. The biogas content in the headspace was collected periodically (every 2 hours) through the butyl cap using a manual gas-tight syringe

linear regression, from samples with concentrations of 3 to $20 \mathrm{mg} \mathrm{L}^{-1}$ of limonene. Three replicates of each standard level were used to build the analytical curve.

\section{Instrumental precision}

Instrumental precision (as coefficient of variation, CV\%) was estimated by the retention time of nine repeated injections of the standard solution with $12 \mathrm{mg} \mathrm{L}^{-1}$ of limonene.

Limit of detection

Detection limit (LD) was calculated according to Equation 1.

$$
L D=3 \times S D / m
$$

where: $\mathrm{SD}=$ standard deviation; $\mathrm{m}=$ angular coefficient 


\section{Limit of quantification}

The lowest possible concentration of measurement was established by quantification limit (LQ), calculated according to Equation 2.

$$
L Q=10 \times S D / m
$$

where: $\mathrm{SD}=$ standard deviation; $\mathrm{m}=$ angular coefficient.

\section{Adsorption assay}

To estimate the adsorption potential of limonene to organic matter, its recovery was measured by the addition of known limonene concentration (2000 $\left.\mathrm{mg} \mathrm{L}^{-1}\right)$ to the sewage sludge used as inoculum in anaerobic reactors. The results were calculated by Equation 3 .

\section{Recovery $(\%)=($ estimated concentration/theoretical concentration $)$} $\times 100$

Limonene adsorption was estimated according to Calabrò et al., ${ }^{1}$ in a control sample (with ultrapure water instead of sewage sludge) and in a sample with $2000 \mathrm{mg} \mathrm{L}^{-1}$ of limonene. To extract this compound, $1 \mathrm{~mL}$ of $\mathrm{n}$-hexane (of analytical purity $>98 \%$ ) was added to each $1 \mathrm{~mL}$ of biomass, and vortexed for 5 minutes, and the procedure was repeated three times. The organic fraction was collected, and the recovery percentage was estimated by the ratio between the estimated concentration in the organic phase and the theoretical concentration.

\section{Applicability}

\section{Kinetics}

The assays were conducted in batch reactors with $5 \mathrm{~g} \mathrm{~L}^{-1}$ of glucose in Duhran flasks with $50 \%$ headspace and $50 \%$ reaction volume, in PCS medium, ${ }^{23}$ under static conditions, at $\mathrm{pH}$ adjusted to 7.0 with $1 \mathrm{~mol} \mathrm{~L}^{-1} \mathrm{NaOH}$ or $\mathrm{HCl}$, with addition of 0 to $2000 \mathrm{mg} \mathrm{L}^{-1}$ of limonene (without limonene addition; 50; 100; 250; 500; 1000; 1500 and $2000 \mathrm{mg} \mathrm{L}^{-1}$ of limonene). The inoculum used was granulated sludge from thermophilic Upflow Anaerobic Sludge Blanket (UASB) applied to sugarcane vinasse treatment (Pradópolis, Brazil) $\left(2 \mathrm{~g} \mathrm{TVS} \mathrm{L}^{-1}\right)$. The inoculum was chosen based on previous research. ${ }^{24}$ After inoculation, a mixture of $\mathrm{N}_{2} / \mathrm{CO}_{2}(70 / 30 \%)$ was fluxed, and the reactors were closed with butyl cap and plastic thread. Limonene concentration was estimated in liquid samples at the beginning and at the end of operation time.

\section{Analytical methods}

Total Solids (TS), Total Volatile Solids (TVS) and $\mathrm{pH}$ determination was performed according to methods 2540B and $2540 \mathrm{E}$, respectively. ${ }^{25}$ Total carbohydrates were quantified according to Dubois et al.,${ }^{26}$ and phenolic compounds were quantified according to Buchanan and Nicell. ${ }^{27}$ Volatile fatty acids and alcohols determination was conducted on a Shimadzu ${ }^{\circledR}$ gas chromatograph (GC-2010) according to Adorno et al. ${ }^{18}$

Biogas composition analysis was performed on a Shimadzu ${ }^{\circledR}$ gas chromatograph (GC-2010), equipped with thermal conductivity detector (DCT). The column used was Carboxen 1010 PLOT, $30 \mathrm{~m}$ x $0.53 \mathrm{~mm}$. Injector, furnace and detector temperatures were $220^{\circ} \mathrm{C}$, $130{ }^{\circ} \mathrm{C}-135^{\circ} \mathrm{C}(5.5 \mathrm{~min})$, at $46{ }^{\circ} \mathrm{C} / \mathrm{min}$ and $230{ }^{\circ} \mathrm{C}$, respectively. Argon was used as carrier gas, with column flow of $5.66 \mathrm{~mL} \mathrm{\textrm {min } ^ { - 1 }}$ and Make-up volume of $12 \mathrm{~mL} \mathrm{~min}^{-1}$.

\section{Data analysis and adjustment}

The time to start the $\mathrm{H}_{2}$ production, maximum $\mathrm{H}_{2}$ production rate and maximum $\mathrm{H}_{2}$ production potential were determinated with the modified Gompertz model. ${ }^{28}$ The kinetic parameters were calculated using Equation 4 in OriginPro 9.0 software.

$$
P_{a c}=P \cdot \exp \left\{-\exp \left(\frac{R m e}{P}[\lambda-t]+1\right)\right\}
$$

where: $\mathrm{Pac}=$ cumulative $\mathrm{H}_{2}$ production, $\mathrm{Rm}=$ maximum $\mathrm{H}_{2}$ production rate $\left(\mathrm{mmol} \mathrm{h}^{-1}\right), \mathrm{e}=$ Euler number $(2.71828182), \lambda=$ time to start the $\mathrm{H}_{2}$ production (h), $\mathrm{P}=$ maximum $\mathrm{H}_{2}$ production potential $\left(\mathrm{mmol} \mathrm{L}^{-1}\right)$.

Shapiro-Wilk normality test was applied to verify data parametricity, that is, if they presented normal distribution $(\mathrm{p} \geq 0.05)$ or non-normal distribution ( $\mathrm{p} \leq 0.05)$. Comparisons were carried out using Kruskal-Wallis or Tukey's test, evaluating statistical relevance at $95 \%$ confidence interval. Experimental data were adjusted to mean values from replicates.

\section{RESULTS AND DISCUSSION}

\section{Calibration curve and validation parameters}

Standard deviations for calibration curve were between 0.5 and $1.8 \mathrm{mg} \mathrm{L}^{-1}$. The method was considered linear for the concentration range studied ( 3 to $20 \mathrm{mg} \mathrm{L}^{-1}$ of limonene). The calibration plot showed good linearity, since the coefficient of correlation $\left(\mathrm{R}^{2}\right)$ was 0.979 (Figure 3).

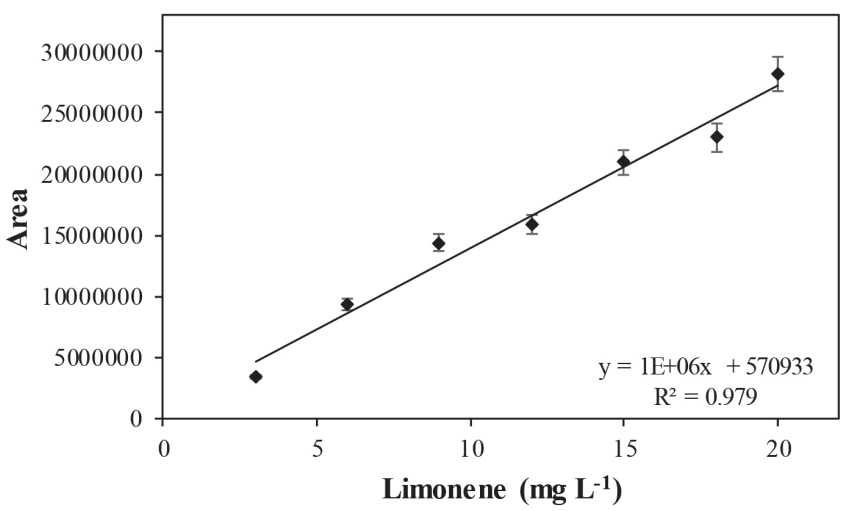

Figure 3. Calibration curve of limonene for 3.0; 6.0; 9.0; 12.0; 15.0; 18.0 and $20.0 \mathrm{mg} \mathrm{L}^{-1}$ of limonene

The peak area corresponding to limonene was determined by chromatogram and mass spectra analysis of a known limonene concentration standard solution. Figure 4.A shows the chromatogram for the standard with $15 \mathrm{mg} \mathrm{L}^{-1}$ of limonene, which corresponds to $15.3 \mathrm{mg} \mathrm{L}^{-1}$ of limonene according to the calibration curve. Figure 4.B shows the chromatogram for assays with $17 \mathrm{mg} \mathrm{L}^{-1}$ of limonene. In addition, the National Institute of Standards and Technology (NIST) library search supported the identification of limonene.

Instrumental precision, estimated as $0.1(\mathrm{CV} \%)$, LD and LQ (1.7 and $4.2 \mathrm{mg} \mathrm{L}^{-1}$, respectively) demonstrates the reliability of the method. The tabulated value for Ftest (ANOVA) was 2.6, while the calculated value was 233.51. The Fcalculated $>$ Ftabulated values are further evidence of method linearity, at a significance level of $95 \%$. The validation parameters evaluated are in accordance with Resolution-Re N. $899^{22}$ and IUPAC Technical Report. ${ }^{29}$

Compared to Davidowski and DiMarco,${ }^{19}$ the method presented here is advantageous over both $\mathrm{GC}$ injector temperature $\left(230^{\circ} \mathrm{C}\right)$ and Oven Program temperature $\left(40{ }^{\circ} \mathrm{C}\right)$, while in the study mentioned, the temperature range was 250 and $80{ }^{\circ} \mathrm{C}$, respectively. Moreover, the method presented in this study allows the analysis of liquid samples 

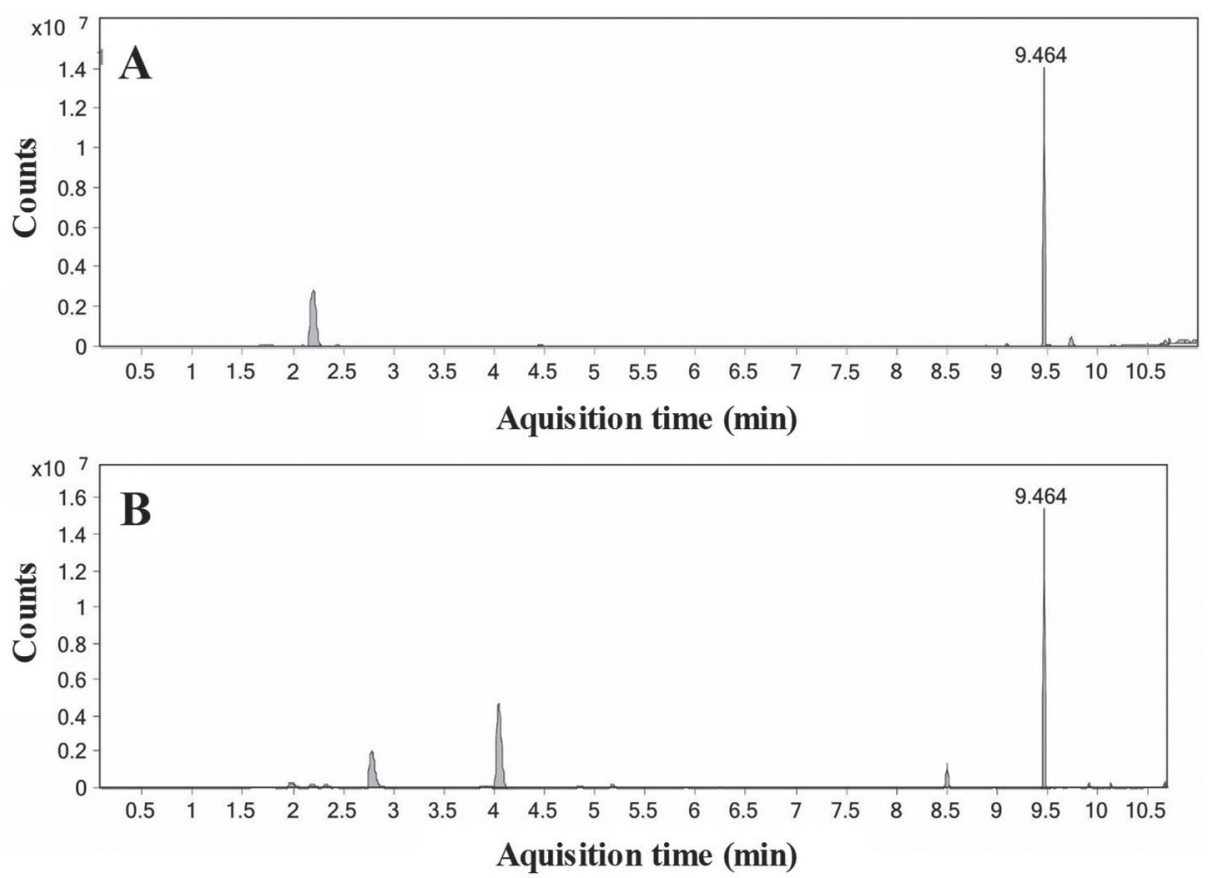

Figure 4. Typical chromatogram of a standard limonene solution $\left(15 \mathrm{mg} \mathrm{L}^{-1}\right)$ (A) and chromatogram for assays with $17 \mathrm{mg} \mathrm{L}^{-1}$ of limonene (B)

from anaerobic reactors, inoculated with impure materials such as sewage sludge, while in Davidowski and DiMarco ${ }^{19}$ the authors used the GC-MS technique for quantification of limonene in orange extract.

\section{Adsorption assay}

Limonene recovery in the control assays (without sewage sludge) was $106.1 \pm 13 \%$ of the theoretical value $\left(2000 \mathrm{mg} \mathrm{L}^{-1}\right)$, while in assays with sewage sludge, $92.3 \pm 0.4 \%$ was recovered. However, this difference was not statistically significant $(\mathrm{p}=0.179)$ for a $95 \%$ confidence interval.

\section{Applicability}

The proposed GC-MS method was applied to determine the limonene concentration at the beginning $(\mathrm{pI})$ and at the end $(\mathrm{pF})$ of the fermentation process of batch anaerobic reactors (Figure 5). There was no significant difference $(\mathrm{p}>0.05)$ between $\mathrm{pI}$ and $\mathrm{pF}$ limonene content. It can be inferred that there was no significant limonene degradation throughout the fermentation process, as well as no significant adsorption of limonene in the sewage sludge used as inoculum, as shown in the adsorption assay. In addition, it can be concluded that the method developed was effective for limonene content analysis determination in anaerobic reactors.

Previous studies indicate that the sorption/desorption equilibrium between limonene and organic matter strongly affects the process. ${ }^{1}$ Calabrò et al. ${ }^{1}$ observed that approximately $76 \%$ of the limonene added to the assays was adsorbed by the solid phase of citrus peel waste. However, a recovery of $97 \%$ of the compound added was observed in this study, with no significant difference between the control (2123 $\left.\mathrm{mg} \mathrm{L}^{-1}\right)$ and assays with sewage sludge (1746 $\left.\mathrm{mg} \mathrm{L}^{-1}\right)$. This difference may have occurred due to the substrate composition

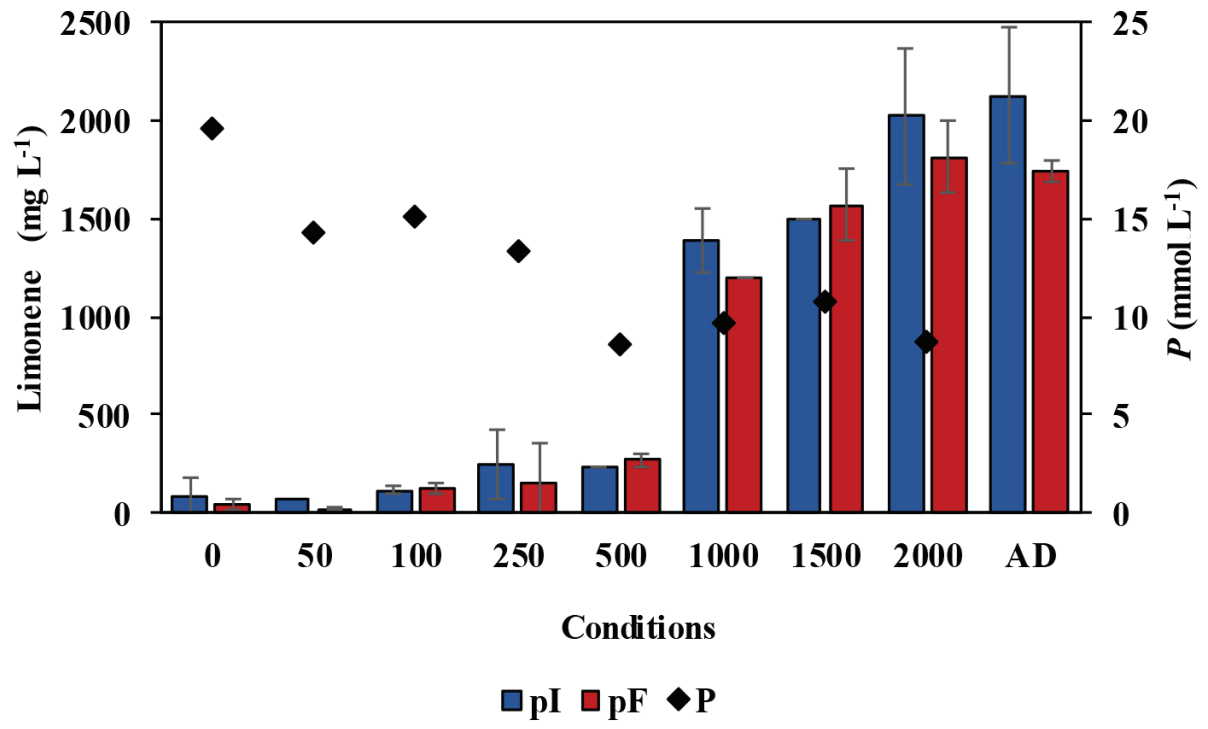

Figure 5. Limonene content at the beginning $(p I)$ and at the end $(p F)$ of the fermentation process of batch anaerobic reactors operated with different concentrations of limonene (without limonene addition to $2000 \mathrm{mg} \mathrm{L}^{-1}$ ) for about 160 hours, adsorption $(A D)$ and $H_{2}$ production potential (P) 
used by the aforementioned authors, since citrus peel waste is rich in long chain waxes, which has a strong affinity with hydrophobic D-limonene.

The effect of different limonene concentrations was determined (without limonene addition to $2000 \mathrm{mg} \mathrm{L}^{-1}$ ) on $\mathrm{H}_{2}$ production potential ( $\mathrm{P}$ mmol L-1 $)$, maximum $\mathrm{H}_{2}$ production rate $\left(\mathrm{Rm} \mathrm{mmol} \mathrm{h}{ }^{-1}\right)$ and start time of $\mathrm{H}_{2}$ production ( $\lambda \mathrm{h}$ ) (Figure 6). Maximum $\mathrm{H}_{2}$ production was $19.5 \mathrm{mmol} \mathrm{L}^{-1}$ in control assays, while the minimum was $8.6 \mathrm{mmol} \mathrm{L}^{-1}$ in assays containing $2000 \mathrm{mg} \mathrm{L}^{-1}$ of limonene. For $95 \%$ confidence interval, it ca be stated that the increase in limonene to $50 \mathrm{mg} \mathrm{L}^{-1}$ and 50 to $100 \mathrm{mg} \mathrm{L}^{-1}$ was not significant. There was no inhibitory effect caused by this compound, while the increase in intervals between 100 and $2000 \mathrm{mg} \mathrm{L}^{-1}$ showed a significant inhibitory effect $(\mathrm{p} \geq 0.05)$ (Table 2).

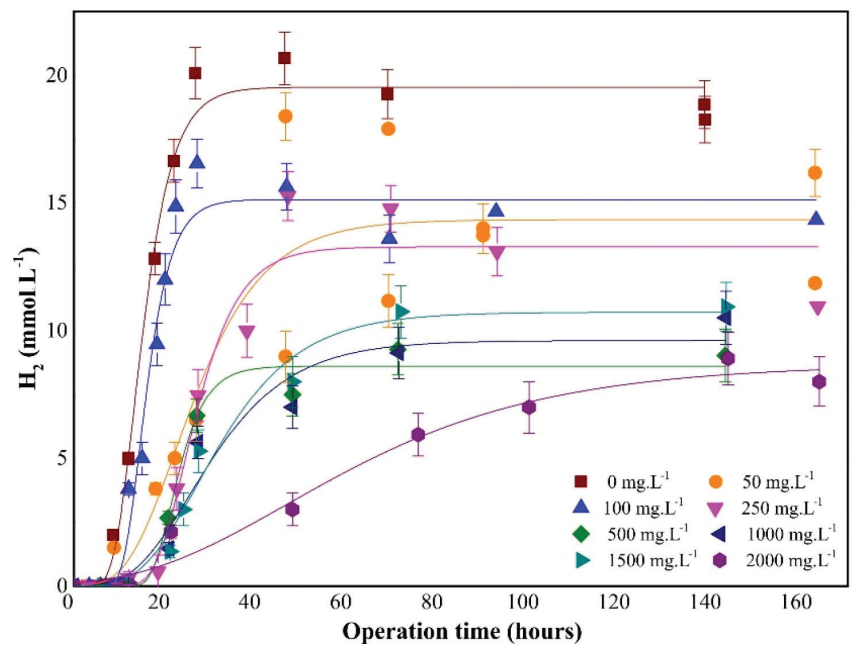

Figure 6. Kinetics of accumulated $\mathrm{H}_{2}$ production in different limonene concentrations (without limonene addition to $2000 \mathrm{mg} \mathrm{L}^{-1}$ )

Table 2. Kinetic parameters of $\mathrm{H}_{2}$ production under different concentrations of limonene (without limonene addition to $2000 \mathrm{mg} \mathrm{L}^{-1}$ ). Means followed by same letter do not differ from each other for a $95 \%$ confidence interval using Kruskal-Wallis test

\begin{tabular}{lcccc}
\hline \multirow{2}{*}{$\begin{array}{l}\text { Limonene } \\
\left.\mathrm{mg} \mathrm{L}^{-1}\right)\end{array}$} & \multicolumn{4}{c}{ Parameters } \\
\cline { 2 - 5 } & $P\left(\mathrm{mmol} \mathrm{L}^{-1}\right)$ & $R m\left(\mathrm{mmol} \mathrm{h}^{-1}\right)$ & $\lambda(\mathrm{h})$ & $\mathrm{R}^{2}$ \\
\hline without & $19.5 \pm 0.4^{\mathrm{a}}$ & $1.7 \pm 0.2^{\mathrm{a}}$ & $8.7 \pm 0.7^{\mathrm{a}}$ & 0.99 \\
50 & $14.3 \pm 1.1^{\mathrm{a}}$ & $0.5 \pm 0.2^{\mathrm{a}}$ & $11.6 \pm 5.9^{\mathrm{a}}$ & 0.97 \\
100 & $15.1 \pm 0.5^{\mathrm{a}}$ & $1.5 \pm 0.2^{\mathrm{b}}$ & $10.8 \pm 0.9^{\mathrm{b}}$ & 0.97 \\
250 & $13.3 \pm 0.7^{\mathrm{c}}$ & $0.7 \pm 0.2^{\mathrm{c}}$ & $17.8 \pm 2.1^{\mathrm{b}}$ & 0.96 \\
500 & $8.6 \pm 0.3^{\mathrm{d}}$ & $0.7 \pm 0.2^{\mathrm{d}}$ & $17.0 \pm 1.3^{\mathrm{b}}$ & 0.98 \\
1000 & $9.6 \pm 0.7^{\mathrm{e}}$ & $0.3 \pm 0.1^{\mathrm{e}}$ & $13.1 \pm 3.5^{\mathrm{b}}$ & 0.95 \\
1500 & $10.7 \pm 0.5^{\mathrm{c}}$ & $0.3 \pm 0.1^{\mathrm{f}}$ & $14.7 \pm 2.1^{\mathrm{b}}$ & 0.98 \\
2000 & $8.7 \pm 0.5^{\mathrm{f}}$ & $0.1 \pm 0.1^{\mathrm{g}}$ & $15.0 \pm 2.3^{\mathrm{b}}$ & 0.97 \\
\hline
\end{tabular}

Likewise, Rm was not significant when $50 \mathrm{mg} \mathrm{L}^{-1}$ of limonene was added $\left(\mathrm{Rm}=0.5 \mathrm{mmol} \mathrm{h}^{-1}\right)$, while the addition in the intervals between 100 and $2000 \mathrm{mg} \mathrm{L}^{-1}$ of limonene delayed the reaction in all assays. The maximum $\mathrm{Rm}$ observed was $1.6 \mathrm{mmol} \mathrm{h}^{-1}$ in control assays and the minimum $\mathrm{Rm}$ was $0.1 \mathrm{mmol} \mathrm{h}^{-1}$ with $2000 \mathrm{mg} \mathrm{L}^{-1}$ of limonene.

For $\lambda$, although there is a proportional increase in limonene concentration, the minimum $\lambda$ was observed for control assay $(17.1 \mathrm{~h})$ and the maximum $\lambda$ for $2000 \mathrm{mg} \mathrm{L}^{-1}$ of limonene assay (37.9 h). However, only the increase from 50 to $100 \mathrm{mg} \mathrm{L}^{-1}$ of limonene showed significant difference for $\lambda$, where $\lambda=11.6 \mathrm{~h}$ to $50 \mathrm{mg} \mathrm{L}^{-1}$ and $\lambda=10.8 \mathrm{~h}$ to $100 \mathrm{mg} \mathrm{L}^{-1}$. This could be explained based on the larger standard deviations of this parameter ${ }^{1}$.

According to Calabrò et al. ${ }^{1}$ only concentrations above 200 $\mathrm{mg} \mathrm{L}^{-1}$ of limonene were inhibitory for methane production with CPW as substrate. In addition, these authors observed an increase in $\lambda$ proportional to limonene concentration increase, as observed in this study.

The aforementioned authors observed significant reduction in $\lambda$ after the biomass adaptation period; however, methane production reached final production values $\left(370 \mathrm{CH}_{4} \mathrm{~g}^{-1} \mathrm{TVS}\right)$ similar to control assays. A greater adaptability of methanogenic organisms after certain period may have occured because of its crystalline surface layer, which confers greater resistance to lipophilic compounds, such as limonene. ${ }^{9}$ These results may have occurred because of the longer reaction time required for methane production (about 4 days) when compared to $\mathrm{H}_{2}$ in this study (about $17.1 \mathrm{~h}$ in control assays), and possible limonene volatilization and/or degradation, minimizing its inhibitory effect over time.

Soares et al. ${ }^{30}$ characterized the same sludge used as inoculum in the present study, observing a relative abundance of $78.2 \%$ for Firmicutes, a bacterial phylum related to $\mathrm{H}_{2}$ production and volatile fatty acids (VFA) as the main metabolites. However, its Gram-positive characteristics may be disadvantageous due to the presence of limonene and other essential oils during fermentation since, according to Ruiz and Flotats, ${ }^{9}$ Gram-positive bacteria can tolerate less concentrations of lipophilic compounds when compared to Gram-negative.

According to Burt, ${ }^{31}$ several operational parameters can affect and increase essential oils toxicity, especially acidic $\mathrm{pH}$. Therefore, since the optimal $\mathrm{pH}$ for acidogenesis and $\mathrm{H}_{2}$ production is considerably lower than the optimum $\mathrm{pH}$ of methanogenic step, it is expected that antimicrobial action in limonene will be potentiated in the first case. In this study, initial $\mathrm{pH}$ was adjusted to 7.0, while $\mathrm{pH}$ after fermentation it reached approximately 5.8, which may have potentiated the limonene inhibitory effect.

Srilatha et $a l . .^{32}$ studied the effect of limonene concentration on citrus residues at mesophilic temperature $\left(30{ }^{\circ} \mathrm{C}\right)$ and $1500 \mathrm{~L}$ digesters, concluding that the maximum daily dosage of limonene would be $24 \mathrm{mg} \mathrm{L}^{-1}$, corresponding to $2.5 \mathrm{~kg}^{\mathrm{TVS} \mathrm{m}} \mathrm{m}^{-1}$ residue per digester. The maximum dosage described by these authors was considerably lower when compared to the present study; however, it should be noted that the authors used CPW, containing approximately $8.9 \mathrm{~g} \mathrm{~kg}^{-1}$ of limonene, whereas in this study the reactors were evaluated by the addition of limonene p.a in batch reactors. Therefore, it is important to consider the inhibitory effect of other essential oils on CPW, not only limonene. ${ }^{9}$

In relation to physical-chemical analysis, TS production was not significant ( $p>0.05)$, as well as the TVS content variation. The variation of other parameters (phenolic compounds, $\mathrm{pH}$ variation and carbohydrate contente) was considered significant ( $\mathrm{p} \leq 0.05)$, and phenolic compounds were produced in all assays, approximately $2 \mathrm{mg} \mathrm{L}^{-1}$, independent of limonene initial concentration. Carbohydrate removal was statistically significant in all assays, with approximately $80 \%$ of the initial carbohydrate concentration (about $5 \mathrm{~g} \mathrm{~L}^{-1}$ ), also independent of initial limonene concentration (Table 3 ).

The $\mathrm{pH}$ variation in different assays was significant $(\mathrm{p} \leq 0.05)$. In addition, an inversely proportional relation between initial limonene concentration and $\mathrm{pH}$ reduction was observed, since in control assays the $\mathrm{pH}$ was 5.9 and in assays with $2000 \mathrm{mg} \mathrm{L}^{-1}$ of limonene the $\mathrm{pH}$ was about 6.3 at the end of the experiments. This result can be related to VFA and $\mathrm{H}_{2}$ production, where in assays with lower limonene concentration $\left(50 \mathrm{mg} \mathrm{L}^{-1}\right)$, higher $\mathrm{H}_{2}$ production was observed 
Table 3. Results of physical-chemical analyses at different concentrations of limonene (without limonene addition to $2000 \mathrm{mg} \mathrm{L}^{-1}$ ) at the beginning ( $\mathrm{pI}$ ) and at the end $(\mathrm{pF})$ of the fermentation process of batch anaerobic reactors.

\begin{tabular}{|c|c|c|c|c|c|c|c|c|}
\hline \multirow{2}{*}{$\begin{array}{l}\text { Limonene } \\
\left(\mathrm{mg} \mathrm{L}^{-1}\right)\end{array}$} & \multicolumn{2}{|c|}{ Carbohydrates $\left(\mathrm{g} \mathrm{L}^{-1}\right)$} & \multicolumn{2}{|c|}{ Phenols (mg L ${ }^{-1}$ ) } & \multicolumn{2}{|c|}{$\mathrm{pH}$} & \multicolumn{2}{|c|}{ TVS (mg L $\left.{ }^{-1}\right)$} \\
\hline & $\mathrm{pI}$ & $\mathrm{pF}$ & $\mathrm{pI}$ & $\mathrm{pF}$ & $\mathrm{pI}$ & $\mathrm{pF}$ & $\mathrm{pI}$ & $\mathrm{pF}$ \\
\hline 0 & $4.9 \pm 0.4$ & $0.3 \pm 0.0$ & $8.0 \pm 0.0$ & $9.1 \pm 0.1$ & $7.2 \pm 0.1$ & $5.9 \pm 0.2$ & $33 \pm 7$ & $42 \pm 5$ \\
\hline 50 & $5.2 \pm 0.1$ & $0.2 \pm 0.0$ & $8.0 \pm 0.0$ & $8.9 \pm 0.1$ & $7.4 \pm 0.1$ & $5.8 \pm 0.3$ & $35 \pm 2$ & $34 \pm 5$ \\
\hline 100 & $5.2 \pm 0.1$ & $0.2 \pm 0.0$ & $8.1 \pm 0.1$ & $9.6 \pm 0.2$ & $7.4 \pm 0.2$ & $6.3 \pm 0.1$ & $49 \pm 13$ & $28 \pm 12$ \\
\hline 250 & $3.2 \pm 0.3$ & $0.1 \pm 0.0$ & $8.3 \pm 0.1$ & $9.8 \pm 0.0$ & $7.1 \pm 0.1$ & $6.1 \pm 0.1$ & $11 \pm 8$ & $23 \pm 15$ \\
\hline 500 & $4.9 \pm 0.6$ & $0.2 \pm 0.0$ & $8.9 \pm 0.1$ & $9.4 \pm 0.0$ & $7.0 \pm 0.1$ & $6.0 \pm 0.2$ & $54 \pm 6$ & $35 \pm 7$ \\
\hline 1000 & $3.5 \pm 0.2$ & $0.1 \pm 0.0$ & $7.8 \pm 0.0$ & $9.3 \pm 0.1$ & $7.3 \pm 0.3$ & $6.4 \pm 0.2$ & $56 \pm 6$ & $47 \pm 11$ \\
\hline 1500 & $3.8 \pm 0.1$ & $0.2 \pm 0.0$ & $7.8 \pm 0.0$ & $9.1 \pm 0.0$ & $7.3 \pm 0.1$ & $6.3 \pm 0.1$ & $42 \pm 6$ & $37 \pm 7$ \\
\hline 2000 & $3.5 \pm 0.1$ & $0.1 \pm 0.0$ & $7.8 \pm 0.0$ & $9.5 \pm 0.3$ & $7.2 \pm 0.1$ & $6.3 \pm 0.1$ & $95 \pm 2$ & $49 \pm 22$ \\
\hline
\end{tabular}

(14.45 $\mathrm{mmol} \mathrm{L}^{-1}$ ) when compared to higher limonene concentrations (2000 $\mathrm{mg} \mathrm{L}^{-1}$ of limonene; $8.7 \mathrm{mmol} \mathrm{H}_{2} \mathrm{~L}^{-1}$ ) (Table 3).

By monitoring the accumulation of VFA and alcohols at the end of operation time, it was observed that there was a difference between the metabolites produced in different limonene concentrations (Figure 7). No production of $\mathrm{HBu}$ was observed in control assays and in assays with $50 \mathrm{mg} \mathrm{L}^{-1}$ of limonene. However, the difference in $\mathrm{H}_{2}$ production between these assays was not significant. Maximum $\mathrm{HBu}$ production was $886 \mathrm{mg} \mathrm{L}^{-1}$ in assays with $100 \mathrm{mg} \mathrm{L}^{-1}$ of limonene.

HAc was the major metabolite in all conditions, with maximum production in the control assay $\left(1771 \mathrm{mg} \mathrm{L}^{-1}\right)$ and lower production in the assay with $2000 \mathrm{mg} \mathrm{L}^{-1}$ of limonene $\left(1024 \mathrm{mg} \mathrm{L}^{-1}\right)$. HAc production was proportional to $\mathrm{H}_{2}$ production, since in control assays $19.5 \mathrm{mmol} \mathrm{H}_{2} \mathrm{~L}^{-1}$ was obtained and in assays with $2000 \mathrm{mg} \mathrm{L}^{-1}$ of limonene $8.68 \mathrm{mmol} \mathrm{H}_{2} \mathrm{~L}^{-1}$ was obtained.

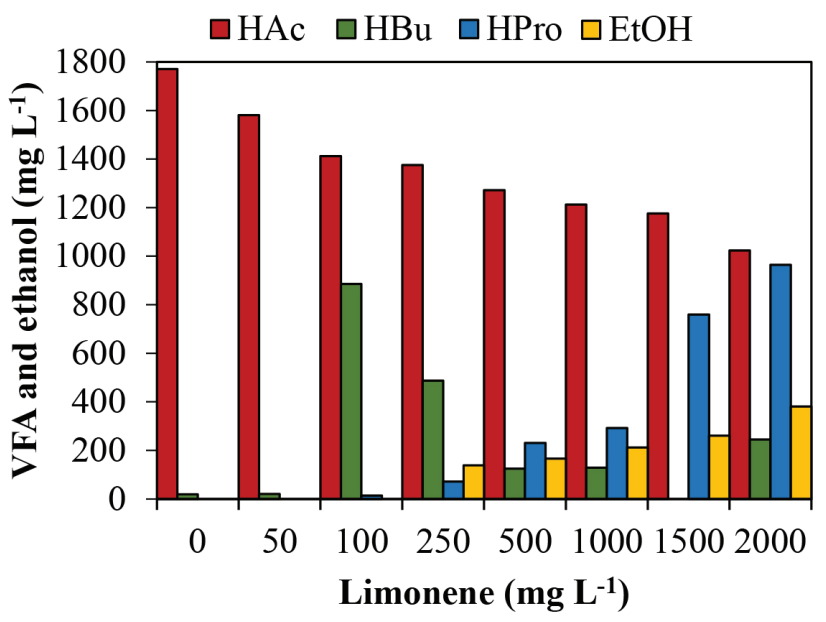

Figure 7. VFA and alcohols accumulated under different conditions. Acetic acid (HAc), butyric acid (HBu), propionic acid (HPro) and ethanol (EtOH)

It is known that acetogenic pathway is more advantageous for $\mathrm{H}_{2}$ production in relation to $\mathrm{HBu}$ pathway, since in the first case, $\mathrm{H}_{2}$ production is about 4 mols per mol of glucose (Equation 5), while in the second case, $\mathrm{H}_{2}$ production is about 2 mols of $\mathrm{H}_{2}$ per mole of glucose (Equation 6). ${ }^{33,34}$ In this study, $0.70 \mathrm{~mol}$ of $\mathrm{H}_{2}$ per mol of glucose was obtained in the control assays, while in assays with the maximum dosage of limonene evaluated $\left(2000 \mathrm{mg} \mathrm{L}^{-1}\right)$, the production was only $0.3 \mathrm{~mol} \mathrm{H}_{2}$ per mol of glucose.

$\mathrm{C}_{6} \mathrm{H}_{12} \mathrm{O}_{6}+6 \mathrm{H}_{2} \mathrm{O} \rightarrow 2 \mathrm{CO}_{2}+2 \mathrm{CH}_{3} \mathrm{COOH}+4 \mathrm{H}_{2}$

$\mathrm{C}_{6} \mathrm{H}_{12} \mathrm{O}_{6}+6 \mathrm{H}_{2} \mathrm{O} \rightarrow 2 \mathrm{CO}_{2}+\mathrm{CH}_{3} \mathrm{CH}_{2} \mathrm{CH}_{2} \mathrm{COOH}+2 \mathrm{H}_{2}$
Likewise, a proportional increase in HPr production was noticed, with an increase of limonene concentration: $14 \mathrm{mgHPr} \mathrm{L}^{-1}$ in assays with $100 \mathrm{mg} \mathrm{L}^{-1}$ of limonene and $964 \mathrm{mgHPr} \mathrm{L}^{-1}$ in assays with $2000 \mathrm{mg} \mathrm{L}^{-1}$ of limonene. In the HPr metabolic pathway, there is a consumption of 2 mols of $\mathrm{H}_{2}$ for each mol of glucose oxidized (Equation 7). ${ }^{35,36}$

$\mathrm{C}_{6} \mathrm{H}_{12} \mathrm{O}_{6}+2 \mathrm{H}_{2} \rightarrow 2 \mathrm{CH}_{3} \mathrm{CH}_{2} \mathrm{COOH}+2 \mathrm{H}_{2} \mathrm{O}$

Ruiz and Flotats ${ }^{7}$ indicate a proportional relation between limonene concentration and $\mathrm{HPr}$ production. These authors obtained $284 \mathrm{mgHPr} \mathrm{L}^{-1}$ after CPW autofermentation, besides $805 \mathrm{mg} \mathrm{HAc} \mathrm{L}^{-1}$ and $909 \mathrm{mgHBu} \mathrm{L}^{-1}$. Similar results were obtained by Su et al. ${ }^{37}$ where in 30 days of fermentation with batch reactors operated with swine manure as inoculum, the main VFA produced from $\mathrm{CPW}$ were $\mathrm{HAc}$ (2610.7 $\left.\mathrm{mg} \mathrm{L}^{-1}\right)$, HPr (56.2 $\left.\mathrm{mg} \mathrm{L}^{-1}\right)$ and $\mathrm{HBu}\left(27.5 \mathrm{mg} \mathrm{L}^{-1}\right)$. In this study, although HAc was the main metabolite pathway in all assays, it was possible to observe a proportional relation between limonene concentration and HPr production, with concomitant reduction in $\mathrm{H}_{2}$ production.

The same pattern was observed for EtOH production, since $139 \mathrm{mgEtOH} \mathrm{L}^{-1}$ was obtained in assays with $250 \mathrm{mg} \mathrm{L}^{-1}$ of limonene and $380 \mathrm{mg} \mathrm{L}^{-1}$ of EtOH in assays with $2000 \mathrm{mg} \mathrm{L}^{-1}$ of limonene. The solvetogenic pathway is not desirable in processes whose main objective is to obtain $\mathrm{H}_{2}$, since there is production of $\mathrm{EtOH}$ from HAc, instead of $\mathrm{H}_{2}$ (Equation 8). ${ }^{33,34}$

$\mathrm{CH}_{3} \mathrm{COOH}+2 \mathrm{H}_{2} \rightarrow \mathrm{CH}_{3} \mathrm{CH}_{2} \mathrm{OH}+\mathrm{H}_{2} \mathrm{O}$

Regarding $\mathrm{H}_{2}$ and VFA production results, it can be inferred that the presence of limonene caused substantial changes in the metabolic pathway prevailing during fermentation in anaerobic reactors.

\section{CONCLUSIONS}

The developed method allowed the determination of limonene in anaerobic reactors, without prior preparation. Because of the simplicity and efficiency of this analysis, this method can be indicated for wastewater characterization and for anaerobic reactors control.

An inhibition effect was observed in $\mathrm{H}_{2}$ and HAc production after limonene addition. This inhibitory effect was significantly proportional to the increase of limonene concentrations, possibly because of changes of metabolic pathway, stimulating EtOH and HPr production. The presence of limonene significantly affected the start time of the $\mathrm{H}_{2}$ production, since in control assays $\lambda=8.7 \mathrm{~h}$ was observed and in assays with $2000 \mathrm{mg}$. $\mathrm{L}^{-1}$ of limonene, $\lambda$ was $15.0 \mathrm{~h}$. 


\section{ACKNOWLEDGEMENTS}

This work was funded by Fundação de Amparo à Pesquisa do Estado de São Paulo (FAPESP) (processes 2017/01722-0, 2015/06246-7 and 2015/15880-1) and was financed in part by the Coordenação de Aperfeiçoamento de Pessoal de Nível Superior Brasil (CAPES) - Finance Code 001.

\section{REFERENCES}

1. Calabrò, P. S.; Pontoni, L.; Porqueddu, I.; Greco, R.; Pirozzi, F.; Malpei F; Waste Manage. 2016, 48, 440.

2. Lotito, A.; M.; De Sanctis, M.; Pastore, C.; Di Iaconi, C.; J. Environ. Manage. 2018, 215, 366.

3. Negro, V.; Ruggeri, B.; Fino, D.; Tonini, D.; Resour. Conserv. Recycl. 2017, 127, 148 .

4. Araújo, A.C. J.; Freitas, P. R.; Barbosa, C. R. S.; Muniz, D. F.; Rocha, J. E.; Silva, A. C. A.; Oliveira-Tintino, C. D. M.; Ribeiro-Filho, J.; Silva, L. E.; Confortin, C.; Amaral, W.; Deschamps, C.; Barbosa-Filho, J. M.; Lima, N. T. R.; Tintino, S. R.; Coutinho, H. D. M.; Food Chem Toxicol. 2020, 136, 111023.

5. Bakkali, F.; Averbeck, S.; Averbeck, D.; Idaomar, M.; Food. Chem. Toxicol. 2008, 46, 446.

6. Lopresto, C. G.; Petrillo, F.; Casazza, A. A.; Aliakbarian, B.; Perego, P.; Calabrò, V.; Sep. Purif. Technol. 2014, 137, 13.

7. Ruiz, B.; Flotats, X.; Biochem. Eng. J. 2016, 109, 9.

8. Pourbafrani, M.; Forgács, G.; Horváth, I. S.; Niklasson, C.; Taherzadeh, M. J.; Bioresour. Technol. 2010, 101, 4246.

9. Ruiz, B.; Flotats, X.; Waste Manage. 2014, 34, 2063.

10. Dorman, H. J. D.; Deans, S. G.; J. Appl. Microbiol. 2000, 88, 308.

11. Ahro, M.; Hakala, M.; Sihvonen, J.; Kauppinen, J.; Kallio, H.; J. Agric. Food Chem. 2001, 49, 3140.

12. Blanch, G. P.; Nicholson, G. J.; J. Chromatogr. Sci. 1998, 36, 19.

13. Song, H. S.; Sawamura, M.; Ito, T.; Kawashimo, K.; Ukeda, H.; Flavour. Fragr. J. 2000, 15, 245.

14. Vautz, W.; Sielemann, S.; Baumbach, J. I.; Anal. Chim. Acta. 2004, 513, 393.

15. Villa, C.; Gambaro, R.; Mariani, E.; Dorato, S.; J. Pharm. Biomed. Anal. 2007, 44, 755

16. Marine, S. S.; Clemons, J.; J. Chromatogr. Sci. 2003, 41, 31
17. Miller, J. A., Hakim, I. A.; Thomson, C.; Thompson, P.; Chow, H. S.; J. Chromatogr. B 2008, 870, 68.

18. Adorno, M. A. T.; Hirasawa, J. S.; Varesche, M. B. A.; Am. J. Anal. Chem. 2014, 5, 406.

19. Davidowski, S.; DiMarco, B.; PerkinElmer Application Note 2009, 1.

20. Ribani, M.; Bottoli, C. B. G.; Collins, C. H.; Jardim, I. C. S. F.; Quim. Nova 2004, 27, 771 .

21. Duarte, I. C. S.; Oliveira, L. L.; Buzzini, A. P.; Adorno, M. A. T.; Varesche, M. B. A.; J. Braz. Chem. Soc. 2006, 17, 1360.

22. Anvisa, Brasil, Diário Oficial da União, 2003, p. 56

23. Haruta, S.; Cui, Z.; Huang, Z.; Li, M.; Ishii, M.; Igarashi, Y.; Appl. Microbiol. Biotechnol. 2002, 59, 529.

24. Camargo, F. P.; Sakamoto, I. K.; Duarte, I. C. S.; Varesche, M. B. A.; Int. J. Hydrogen. Energy. 2019, 44, 22888.

25. APHA/AWWA/WEF; Standard Methods for the Examination of Water and Wastewater, 22 ${ }^{\text {th }}$ ed., American Public Health Association: Washington, DC, 2012.

26. Dubois, M.; Gilles, K.; Hamilton, J.; Rebers, P.; Smith, F.; Anal. Chem. 1956, 28, 350 .

27. Buchanan, I. D.; Nicell, J. A.; Biotechnol. Bioeng. 1997, 54, 251.

28. Zwietering, M. H.; De Wit, J. C.; Cuppers, H. G. A. M.; Van't Riet, K.; Appl. Environ. Microbiol. 1994, 60, 204.

29. Thompson, M.; Ellison, S. L. R.; Wood, R.; IUPAC Techinal Reports2002, 74, 835.

30. Soares, L. A.; Braga, J. K.; Motteran, F.; Sakamoto, I. K.; Monteiro, P. A. S.; Seleghim Jr., P.; Varesche, M. B. A.; Waste Biomass Valorization 2019, 7, 1899.

31. Burt, S.; Int. J. Food Microbiol. 2004, 94, 223.

32. Srilatha, H. R.; Nand, K.; Babu, K. S.; Madhukara, K.; Process. Biochem. 1995, 30, 327.

33. Mäkinen, A. E.; Nissilä, M. E.; Puhakka, J. A.; Int. J. Hydrogen Energy 2012, 37, 12234

34. Łukajtis, R.; Hołowacz, I.; Kucharska, K.; Glinka, M.; Rybarczyk, P.; Przyjazny, A.; Kamiński, M.; Renewable Sustainable Energy Rev. 2018. 91, 665 .

35. Ghimire, A.; Frunzo, L.; Pirozzi, F.; Trably, E.; Escudie, R.; Lens, P. N. L.; Esposito, G.; Appl. Energy 2015, 144, 73.

36. Li, C.; Fang, H. H. P.; Crit. Rev. Environ. Sci. Technol. 2007, 37, 1.

37. Su, H.; Tan, F.; Xu, Y.; Fuel 2016, 181, 843 